\title{
Detection of EBV Infection and Gene Expression in Oral Cancer from Patients in Taiwan by Microarray Analysis
}

\section{Ching-Yu Yen, ${ }^{1,2}$ Min-Chi Lu, ${ }^{3}$ Ching-Cherng Tzeng, ${ }^{4}$ Jia-Yan Huang, ${ }^{5}$ Hsueh-Wei Chang, ${ }^{6}$ Ruey-Shyang Chen, ${ }^{7}$ Shyun-Yeu Liu, ${ }^{1}$ Shih-Tung Liu, ${ }^{8}$ Biehuoy Shieh, ${ }^{5}$ and Ching Li ${ }^{3,9}$}

\author{
${ }^{1}$ Department of Oral and Maxillofacial Surgery, Chi-Mei Medical Center, Tainan 710, Taiwan \\ ${ }^{2}$ School of Dentistry, Taipei Medical University, Taipei 110, Taiwan \\ ${ }^{3}$ Department of Microbiology and Immunology, Chung Shan Medical University, Taichung 402, Taiwan \\ ${ }^{4}$ Department of Pathology, Chi-Mei Medical Center, Tainan 710, Taiwan \\ ${ }^{5}$ Department of Biochemistry, Chung Shan Medical University, Taichung 402, Taiwan \\ ${ }^{6}$ Department of Biomedical Science and Environmental Biology, Kaohsiung Medical University, Kaohsiung 807, Taiwan \\ ${ }^{7}$ Department of Biochemical Science and Technology, National Chiayi University, Chiayi 600, Taiwan \\ ${ }^{8}$ Department of Microbiology and Immunology, Chang-Gung University College of Medicine, Taoyuan 333, Taiwan \\ ${ }^{9}$ Department of Microbiology and Immunology, National Chiayi University, Chiayi 600, Taiwan
}

Correspondence should be addressed to Ching Li, chingli@mail.ncyu.edu.tw

Received 30 April 2009; Accepted 12 September 2009

Recommended by Decheng Yang

Epstein-Barr virus is known to cause nasopharyngeal carcinoma. Although oral cavity is located close to the nasal pharynx, the pathogenetic role of Epstein-Barr virus (EBV) in oral cancers is unclear. This molecular epidemiology study uses EBV genomic microarray (EBV-chip) to simultaneously detect the prevalent rate and viral gene expression patterns in 57 oral squamous cell carcinoma biopsies (OSCC) collected from patients in Taiwan. The majority of the specimens (82.5\%) were EBV-positive that probably expressed coincidently the genes for EBNAs, LMP2A and 2B, and certain structural proteins. Importantly, the genes fabricated at the spots 61 (BBRF1, BBRF2, and BBRF3) and 68 (BDLF4 and BDRF1) on EBV-chip were actively expressed in a significantly greater number of OSCC exhibiting exophytic morphology or ulceration than those tissues with deep invasive lesions $(P=.0265$ and .0141 , resp.). The results may thus provide the lead information for understanding the role of EBV in oral cancer pathogenesis.

Copyright ( $) 2009$ Ching-Yu Yen et al. This is an open access article distributed under the Creative Commons Attribution License, which permits unrestricted use, distribution, and reproduction in any medium, provided the original work is properly cited.

\section{Introduction}

Most oral cancer is squamous cell carcinoma that originates from outgrowth of the mucosal epithelium. Ulcerative and irregular surfaces at the border of cancerous tissues are the most common morphologic manifestations. Not only is the tumor resistant to therapeutic treatments but also it is accompanied frequently with serious pain, especially in patients at late stages [1]. In recent years, the prevalence rate for oral cancer in Taiwan has dramatically increased. The statistical data published in 2004 Taiwanese Health and Vital Statistics (Department of Health or DOH, Taiwan, ROC) showed that the oral cancer incidence rate in Taiwan is 1.5 to more than 4-folds higher than that in Germany, Japan,
Korea, Singapore, the UK, or the USA. In fact, the oral cancer incidence rate among Taiwanese males steadily increased over the years and reached 22.7 and 25.3 per 100000 in 1998 and 1999, respectively. These figures are at least double of those found in USA (1975-2003 SEER Cancer Statistics Review, National Cancer Institute, USA) and markedly higher than those in some European (Spain and France) and Asian (Cambodia and Bangladesh) countries, as revealed in a survey conducted by the International Agency for Research on Cancer (IARC) in 2002. Unsurprisingly, according to Cancer Registry Report, 2005 published (on April 11, 2008) by Bureau of Health Promotion, DOH in Taiwan, oral cancer was the number one cancer among males of 25 to 44 years old. Therefore, the control of oral cancer and improving 
the outcomes of treatments have become urgent issues for Taiwan.

Many factors, including the habit of betel quid chewing [2] and viral infections, have been investigated for their association with the tumorigenesis of oral cancer, in the hope to gain a better understanding of the biology of the cancer and possibly develop effective means to increase the overall survival rate. Although the oral cavity, which contains a large area of the epithelium, is located close to the nasal pharynx, the association of oral cancer with Epstein-Barr virus (EBV) is uncertain, but infection by the virus has been linked to nasopharyngeal carcinoma (NPC) $[3,4]$. EBV, a $\gamma$-herpesvirus, is ubiquitously present in the human population. Infection by EBV is known to cause infectious mononucleosis and is associated with many human lymphoid and epithelial cancers, including Burkitt's lymphoma, gastric cancer, T cell lymphoma, Hodgkin's disease, and NPC [3,5]. Many studies have shown that the expression of viral latent genes, especially genes for EBNAs (EBV-associated nuclear antigens) and LMP-1 (latent membrane protein-1), has been closely associated with latent infection that correlates with immortalization and tumorigenesis. In recent years, more evidences show that EBV is found in tumors of bladder [6], breast [7], cervix [8], gastric [9] or gastrointestinal tract [10], kidney [11], lung [12], skin [13], and thyroid [14]. Unfortunately, the role of the virus in the formation of these cancers remains uncertain. Owing to the increase in EBV detection in many cancers, numerous molecular surveys on oral cancer, which used mainly polymerase chain reaction (PCR) and in situ hybridization methods to detect viral DNA and RNA transcripts, have been performed in many geographic areas worldwide, including Asian and European countries. Among those investigations reporting the detection of EBV in oral squamous cell carcinomas (OSCCs) in the past decade, the viral prevalent rates varied greatly, ranging from $15 \%$ to $77 \%$ [15-24], whereas few studies showed the total absence of EBV in the OSCC specimens $[25,26]$. These discrepancies in viral prevalent rates may have been attributed to the methods of cancer biopsy preparation and preservation, the selections of gene targets, and/or the techniques of detections. In EBV-positive OSCC, only a limited number of viral genes have been screened for their expressions; EBER and EBNA2 transcripts were analyzed by in situ hybridization [17, 20, 22, 26, 27] and EBNA1, EBNA2, LMP-1, ZEBRA, and Zta proteins were stained by immunological methods $[17,20,22,27]$. Although great efforts had been made in these studies, the etiologic and tumorigenic roles of the virus in oral cancer remain unclear.

The recent advance in microarray technology allows scientists to fast and simultaneously detect different viral genomic sequences or globally profile the viral gene expression patterns with a great specificity and sensitivity; the most substantial and feasible case has been the demonstration of developing and analyzing the opportunistic viral infections in AIDS pathogenesis with a multivirus array containing eight human viruses [28]. In order to determine accurately the prevalent rate for the potential viral etiologic agent in
OSCC, newly developed EBV genomic microarray (EBVchip) $[29,30]$ is used in the current study. EBV-chip, which contains viral DNA spots covering the entire EBV genome, is hybridized with biotin-labeled cDNA derived from OSCC biopsies for detecting the presence of viral transcripts. This determines simultaneously the viral infection rate and the gene expression patterns in the cancer tissues studied. The hybridization method has not only similar sensitivity as PCR [31] but also the advantage of preventing false PCR identification due to carry-over contaminations. Furthermore, since the viral genomic microarray can detect multiple gene transcripts simultaneously, which cannot be achieved by other hybridization methods, the reliability of positive identification of EBV present in tumor cells is greatly increased. This study finds that 47 out of 57 OSCC specimens were EBV-positive that expressed coincidently the genes for EBNAs, LMP2A and 2B, and certain structural proteins. Importantly, the genes fabricated at the spots 61 and 68 on EBV-chip were actively expressed in a significantly greater number of OSCC exhibiting exophytic morphology or ulceration than those tissues with deep invasive lesions. The results of EBV-chip hybridization may thus provide the lead information for understanding the role of EBV in oral cancer pathogenesis.

\section{Materials and Methods}

2.1. Patients and Cell Lines. OSCC tissue specimens were collected from patients who were admitted to the hospital and underwent surgical procedures between 1999 and 2002 under patients' consent. After surgery, all patients were subjected to follow-ups for at least four years to evaluate their prognostic progresses. The general characteristics and clinical findings of the patients are listed and summarized in Tables 1 and 2, respectively. Cell lines used in this study included B95-8, which was EBV-infected marmoset blood leukocytes with continuous viral replication, and P3HR1, which was derived from Burkitt's lymphoma and was latently infected by EBV. B95-8 and P3HR1 cells were cultured in RPMI 1640 medium (GIBCO, Invitrogen, Grand Island, NY, USA) supplemented with $10 \%$ bovine calf serum (HyClone, Logan UT, USA) and 1\% PenicillinStreptomycin (GIBCO). The EBV lytic cycle in P3HR1 cells was induced with $3 \mathrm{ng} / \mathrm{mL}$ of $12-O$-tetradecanoylphorbol13 -acetate (TPA; GIBCO) and $3 \mathrm{mM}$ sodium butyrate (SB; Sigma-Aldrich, St. Louise, MO, USA). Enzymes used in this study were purchased from Stratagen (La Jolla, CA, USA) unless otherwise specified; common chemicals and reagents were from Sigma-Aldrich.

2.2. Microarray Analysis and Real-Time RT-PCR Confirmation. EBV-chip was produced according to a method described elsewhere [29]. This viral genome microarray was fabricated with 71 consecutive PCR-amplified EBV DNA fragments of $1-3 \mathrm{kbp}$ covering the entire $172-\mathrm{kbp}$ viral genome and 12 control gene fragments, including the genes for human $\beta$-actin and glyceraldehyde-3-phosphate dehydrogenase (GAPDH) $[29,30]$. The organization of 
TABLE 1: Characteristics of patient subjects participated in EBV-chip detection.

\begin{tabular}{|c|c|c|c|c|c|}
\hline Number $^{(a)}$ & Gender & Age & Number of lesion $^{(b)}$ & Site Sc) $^{(\mathrm{c})}$ & Type of the primary SCC \\
\hline 1 & Male & 50 & 1 & Palate & Ulcerative \\
\hline 2 & Male & 47 & 3 & $\begin{array}{c}\text { Primary: Buccal mucosa, SCC } \\
\text { Secondary: Buccal mucosa, Leukoplakia } \\
\text { Tertiary: Palate, VH }\end{array}$ & Exophytic \\
\hline 3 & Male & 47 & 1 & Gingiva & Exophytic \\
\hline 4 & Male & 46 & 1 & $\begin{array}{c}\text { Palate } \\
\text { Primary: Buccal mucosa, SCC }\end{array}$ & Exophytic \\
\hline 5 & Male & 48 & 3 & $\begin{array}{l}\text { Secondary: Buccal mucosa, SCC } \\
\text { Tertiary: Buccal mucosa, VH }\end{array}$ & Exophytic \\
\hline 6 & Male & 79 & 1 & $\begin{array}{c}\text { Buccal mucosa } \\
\text { Primary: Tongue, SCC }\end{array}$ & Ulcerative \\
\hline 7 & Male & 51 & 3 & $\begin{array}{c}\text { Secondary: Tongue, SCC } \\
\text { Tertiary: Buccal mucosa, SCC }\end{array}$ & Ulcerative \\
\hline 8 & Male & 49 & 4 & $\begin{array}{c}\text { Primary: Palate, SCC } \\
\text { Secondary: Palate, SCC } \\
\text { Tertiary: Buccal mucosa, VH } \\
\text { Quaternary: Lip, VH }\end{array}$ & Exophytic \\
\hline 9 & Male & 47 & 1 & Retromolar trigone & Ulcerative \\
\hline 10 & Male & 53 & 1 & $\begin{array}{c}\text { Gingiva } \\
\text { Primary: Buccal mucosa, SCC }\end{array}$ & Ulcerative \\
\hline 11 & Male & 47 & 3 & $\begin{array}{l}\text { Secondary: Buccal mucosa, SCC } \\
\text { Tertiary: Gingiva, Leukoplakia }\end{array}$ & Exophytic \\
\hline 12 & Male & 50 & 1 & Buccal mucosa & Exophytic \\
\hline 13 & Male & 53 & 1 & Buccal mucosa & Exophytic \\
\hline 14 & Male & 47 & 1 & Gingiva & Ulcerative \\
\hline 15 & Male & 45 & 1 & Gingiva & Ulcerative \\
\hline 16 & Male & 44 & 1 & Tongue & Ulcerative \\
\hline 17 & Male & 47 & 4 & $\begin{array}{l}\text { Primary: Buccal mucosa, SCC } \\
\text { Secondary: Buccal mucosa, SCC } \\
\text { Tertiary: Retromolar trigone, SH } \\
\text { Quaternary: Lip, SH }\end{array}$ & Exophytic \\
\hline 18 & Male & 56 & 1 & Buccal mucosa & Exophytic \\
\hline 19 & Male & 36 & 1 & Gingiva & Ulcerative \\
\hline 20 & Male & 49 & 2 & $\begin{array}{c}\text { Primary: Buccal mucosa, SCC } \\
\text { Secondary: Tongue, VH }\end{array}$ & Ulcerative \\
\hline 21 & Male & 46 & 1 & $\begin{array}{c}\text { Tongue } \\
\text { Primary: Gingiva, SCC }\end{array}$ & Deep invasive \\
\hline 22 & Male & 43 & 3 & $\begin{array}{c}\text { Secondary: Buccal mucosa, SCC } \\
\text { Tertiary: Gingiva, VH }\end{array}$ & Ulcerative \\
\hline 23 & Male & 53 & 1 & $\begin{array}{c}\text { Tongue } \\
\text { Primary: Buccal mucosa, SCC }\end{array}$ & Ulcerative \\
\hline 24 & Male & 52 & 4 & $\begin{array}{c}\text { Secondary: Buccal mucosa, SCC } \\
\text { Tertiary: Palate, VH } \\
\text { Quaternary: Lip, VH } \\
\text { Primary: Gingiva, SCC }\end{array}$ & Exophytic \\
\hline 25 & Male & 65 & 4 & $\begin{array}{c}\text { Secondary: Gingiva, SCC } \\
\text { Tertiary: Gingiva, VH } \\
\text { Quaternary: Oropharynx, VH }\end{array}$ & Exophytic \\
\hline 26 & Male & 59 & 1 & Gingiva & Ulcerative \\
\hline 27 & Male & 41 & 1 & Buccal mucosa & Exophytic \\
\hline 28 & Male & 54 & 1 & Tongue & Exophytic \\
\hline 29 & Male & 75 & 1 & Gingiva & Ulcerative \\
\hline 30 & Male & 32 & 1 & Buccal mucosa & Exophytic \\
\hline
\end{tabular}


TABle 1: Continued.

\begin{tabular}{|c|c|c|c|c|c|}
\hline Number $^{(a)}$ & Gender & Age & Number of lesion ${ }^{(b)}$ & Site $e^{(\mathrm{c})}$ & Type of the primary SCC \\
\hline 31 & Male & 33 & 2 & $\begin{array}{l}\text { Primary: Buccal mucosa, SCC } \\
\text { Secondary: Buccal mucosa, VH }\end{array}$ & Deep invasive \\
\hline 32 & Male & 48 & 1 & Tongue & Exophytic \\
\hline 33 & Male & 54 & 4 & $\begin{array}{c}\text { Primary: Buccal mucosa, SCC } \\
\text { Secondary: Buccal mucosa, SCC } \\
\text { Tertiary: Buccal mucosa, SCC } \\
\text { Quaternary: Lip, SCC }\end{array}$ & Exophytic \\
\hline 34 & Male & 47 & 1 & Buccal mucosa & Exophytic \\
\hline 35 & Male & 40 & 1 & Palate & Ulcerative \\
\hline 36 & Male & 34 & 1 & Tongue & Deep invasive \\
\hline 37 & Male & 58 & 3 & $\begin{array}{c}\text { Primary: Buccal mucosa, SCC } \\
\text { Secondary: Buccal mucosa, SCC } \\
\text { Tertiary: Tongue, VH }\end{array}$ & Exophytic \\
\hline 38 & Male & 61 & 1 & Buccal mucosa & Ulcerative \\
\hline 39 & Male & 61 & 1 & Buccal mucosa & Ulcerative \\
\hline 40 & Male & 75 & 1 & Retromolar trigone & Deep invasive \\
\hline 41 & Male & 45 & 1 & Mouth floor & Ulcerative \\
\hline 42 & Male & 41 & 4 & $\begin{array}{c}\text { Primary: Buccal mucosa, SCC } \\
\text { Secondary: Buccal mucosa, SCC } \\
\text { Tertiary: Palate, Leukoplakia } \\
\text { Quaternary: Lip, SCC }\end{array}$ & Deep invasive \\
\hline 43 & Male & 45 & 1 & Tongue & Exophytic \\
\hline 44 & Male & 43 & 1 & $\begin{array}{c}\text { Tongue } \\
\text { Primary: Tongue, SCC }\end{array}$ & Exophytic \\
\hline 45 & Male & 46 & 3 & $\begin{array}{c}\text { Secondary: Tongue, SCC } \\
\text { Tertiary: Buccal mucosa, VH } \\
\text { Primary: Lip, SCC }\end{array}$ & Exophytic \\
\hline 46 & Female & 70 & 3 & $\begin{array}{c}\text { Secondary: Lip, SCC } \\
\text { Tertiary: Buccal mucosa, Leukoplakia } \\
\text { Primary: Mouth floor, SCC }\end{array}$ & Deep invasive \\
\hline 47 & Male & 47 & 3 & $\begin{array}{c}\text { Secondary: Mouth floor, SCC } \\
\text { Tertiary: Lip, VH }\end{array}$ & Exophytic \\
\hline 48 & Male & 48 & 1 & $\begin{array}{c}\text { Buccal mucosa } \\
\text { Primary: Buccal mucosa, SCC }\end{array}$ & Ulcerative \\
\hline 49 & Male & 62 & 3 & $\begin{array}{c}\text { Secondary: Buccal mucosa, SCC } \\
\text { Tertiary: Tongue, SCC }\end{array}$ & Deep invasive \\
\hline 50 & Male & 44 & 3 & $\begin{array}{l}\text { Primary: Buccal mucosa, SCC } \\
\text { Secondary: Tongue, Leukoplakia } \\
\text { Tertiary: Mouth floor, Leukoplakia }\end{array}$ & Ulcerative \\
\hline 51 & Male & 43 & 1 & Buccal mucosa & Deep invasive \\
\hline 52 & Male & 51 & 1 & Buccal mucosa & Ulcerative \\
\hline 53 & Male & 51 & 1 & Buccal mucosa & Exophytic \\
\hline 54 & Male & 51 & 1 & Buccal mucosa & Exophytic \\
\hline 55 & Male & 42 & 1 & Buccal mucosa & Exophytic \\
\hline 56 & Male & 54 & 1 & Buccal mucosa & Deep invasive \\
\hline 57 & Female & 26 & 4 & $\begin{array}{c}\text { Primary: Buccal mucosa, SCC } \\
\text { Secondary: Buccal mucosa SCC } \\
\text { Tertiary: Mouth floor, Leukoplakia } \\
\text { Quaternary: Tongue, SCC }\end{array}$ & Ulcerative \\
\hline
\end{tabular}

(a) The sequential case numbers were given in the order of the date of admission to hospital.

(b) Twenty oral cancer patients were found to manifest multiple tumor lesions when performing follow-ups 48 months after surgical procedures.

(c) For patients with multiple lesions, the sites and the pathologic diagnosis of all lesions were noted. In the current study, only the primary cancer tissues were subjected to EBV-chip hybridizations. SCC: squamous cell carcinoma; VH: verrucous hyperplasia; SH: squamous hyperplasia. 
TABLE 2: Summary of the clinical characteristics of the studied patients.

\begin{tabular}{lcc}
\hline Overall: 57 patients & EBV-negative: 10 patients & EBV-positive: 47 patients \\
\hline Gender & Gender & Gender \\
Famale: 2 & Famale: 0 & Famale: 2 \\
Male: 55 & Male: 10 & Male: 45 \\
Ave. age & Ave. age & Ave. age \\
49.4 years old & 53.1 years old & 48.6 years old \\
Multiplicity & Multiplicity & Multiplicity \\
Single primary tumor: 37 & Single primary tumor: 7 & Single primary tumor: 30 \\
Multiple primary tumor: 20 & Multiple primary tumor: 3 & Multiple primary tumor: 17 \\
Site of the primary cancer & Site of the primary cancer & Site of the primary cancer \\
Buccal mucosa: 29 & Buccal mucosa: 7 & Buccal mucosa: 22 \\
Gingiva: 9 & Gingiva: 1 & Gingiva: 8 \\
Lip: 1 & Lip: 0 & Lip: 1 \\
Mouth floor: 2 & Mouth floor: 1 & Mouth floor: 1 \\
Palate: 4 & Palate: 0 & Palate: 4 \\
Retromolar trigone: 2 & Retromolar trigone: 1 & Retromolar trigone: 1 \\
Tongue: 10 & Tongue: 0 & Tongue: 10 \\
Type & Type & Type \\
Deep invasive lesion: 9 & Deep invasive lesion: 2 & Deep invasive lesion: 7 \\
Exophytic lesion: 26 & Exophytic lesion: 2 & Exophytic lesion: 24 \\
Ulcerative lesion: 22 & Ulcerative lesion: 6 & Ulcerative lesion: 16
\end{tabular}

TABLE 3: Arbitrary viral gene expression levels in EBV-negative oral cancer specimens.

\begin{tabular}{|c|c|c|c|c|c|c|c|c|c|c|c|c|}
\hline \multirow{2}{*}{ Spot on Chip ${ }^{(a)}$} & \multicolumn{10}{|c|}{ Case Number $^{(\mathrm{b})}$ and Gene Expression Level ${ }^{(\mathrm{c})}$} & \multirow{2}{*}{ Mean $^{(d)}$} & \multirow{2}{*}{ Mean $+2 \mathrm{SD}^{(\mathrm{e})}$} \\
\hline & 6 & 15 & 20 & 27 & 31 & 38 & 40 & 41 & 50 & 54 & & \\
\hline 1 & 1429 & 1794 & 1034 & 999 & 4215 & 1428 & 7001 & 1610 & 1956 & 2418 & 2388 & 6122 \\
\hline 2 & 124 & 646 & 835 & 449 & 1966 & 539 & 3649 & 235 & 11 & 504 & 896 & 3116 \\
\hline 3 & 5 & 660 & 988 & 0 & 701 & 1 & 148 & 0 & 0 & 139 & 264 & 1008 \\
\hline 4 & 139 & 204 & 222 & 0 & 392 & 0 & 48 & 0 & 0 & 6 & 101 & 371 \\
\hline 5 & 25 & 518 & 1490 & 0 & 1016 & 0 & 182 & 0 & 17 & 747 & 400 & 1457 \\
\hline 6 & 36 & 8997 & 6073 & 7026 & 1456 & 3038 & 11046 & 1531 & 3268 & 2999 & 4547 & 11722 \\
\hline $\mathrm{R}$ & 3778 & 1766 & 2435 & 3905 & 3459 & 6762 & 11277 & 2487 & 3788 & 4620 & 4428 & 9976 \\
\hline 27 & 153 & 256 & 1109 & 1 & 1503 & 138 & 135 & 0 & 0 & 254 & 355 & 1392 \\
\hline 28 & 0 & 6621 & 1534 & 1683 & 6549 & 2578 & 10069 & 84 & 27 & 49 & 2919 & 10060 \\
\hline 29 & 0 & 75 & 42 & 0 & 206 & 0 & 76 & 0 & 0 & 0 & 40 & 173 \\
\hline 30 & 4 & 3 & 6 & 0 & 64 & 0 & 88 & 0 & 0 & 0 & 17 & 80 \\
\hline 31 & 439 & 110 & 136 & 0 & 102 & 0 & 113 & 0 & 0 & 0 & 90 & 361 \\
\hline 32 & 0 & 0 & 55 & 0 & 695 & 0 & 2 & 0 & 0 & 0 & 75 & 512 \\
\hline 33 & 98 & 4 & 7 & 0 & 502 & 0 & 0 & 0 & 0 & 1164 & 178 & 938 \\
\hline 34 & 23 & 390 & 937 & 0 & 4344 & 0 & 56 & 0 & 0 & 603 & 635 & 3321 \\
\hline 35 & 224 & 1036 & 1158 & 1464 & 1793 & 814 & 2524 & 342 & 0 & 1006 & 1036 & 2564 \\
\hline 36 & 525 & 2286 & 1127 & 93 & 1208 & 0 & 1 & 150 & 164 & 23 & 558 & 2075 \\
\hline 37 & 0 & 139 & 9 & 2 & 286 & 0 & 0 & 0 & 11 & 0 & 45 & 235 \\
\hline 38 & 0 & 76 & 27 & 0 & 364 & 0 & 0 & 0 & 4 & 0 & 47 & 275 \\
\hline 39 & 0 & 147 & 76 & 0 & 2410 & 45 & 0 & 0 & 42 & 0 & 272 & 1777 \\
\hline 40 & 0 & 0 & 61 & 0 & 284 & 0 & 8 & 0 & 0 & 0 & 35 & 214 \\
\hline 41 & 0 & 0 & 12 & 0 & 684 & 0 & 0 & 4 & 0 & 12 & 71 & 502 \\
\hline 42 & 0 & 17 & 0 & 0 & 357 & 0 & 4 & 0 & 0 & 0 & 38 & 262 \\
\hline 43 & 25 & 18 & 0 & 0 & 847 & 0 & 73 & 0 & 0 & 0 & 96 & 626 \\
\hline 44 & 177 & 1233 & 566 & 12 & 802 & 0 & 0 & 509 & 421 & 0 & 372 & 1207 \\
\hline 45 & 0 & 118 & 322 & 0 & 571 & 43 & 0 & 18 & 74 & 0 & 115 & 492 \\
\hline
\end{tabular}


Table 3: Continued.

\begin{tabular}{|c|c|c|c|c|c|c|c|c|c|c|c|c|}
\hline \multirow{2}{*}{ Spot on Chip ${ }^{(\mathrm{a})}$} & \multicolumn{10}{|c|}{ Case Number ${ }^{(\mathrm{b})}$ and Gene Expression Level ${ }^{(\mathrm{c})}$} & \multirow{2}{*}{ Mean $^{(d)}$} & \multirow{2}{*}{ Mean $+2 \mathrm{SD}^{(\mathrm{e})}$} \\
\hline & 6 & 15 & 20 & 27 & 31 & 38 & 40 & 41 & 50 & 54 & & \\
\hline 46 & 0 & 221 & 0 & 0 & 181 & 0 & 0 & 4 & 75 & 4 & 49 & 217 \\
\hline 47 & 0 & 54 & 71 & 0 & 345 & 0 & 0 & 0 & 12 & 0 & 48 & 263 \\
\hline 48 & 0 & 46 & 0 & 0 & 689 & 0 & 8 & 4 & 18 & 0 & 77 & 508 \\
\hline 49 & 0 & 6 & 91 & 0 & 923 & 0 & 3 & 0 & 4 & 0 & 103 & 682 \\
\hline 50 & 2 & 14 & 145 & 8 & 751 & 0 & 1 & 0 & 0 & 10 & 93 & 564 \\
\hline 51 & 15 & 51 & 60 & 0 & 114 & 0 & 0 & 0 & 2 & 93 & 34 & 120 \\
\hline 52 & 421 & 5377 & 1626 & 3518 & 3597 & 643 & 1388 & 2389 & 4402 & 1548 & 2491 & 5812 \\
\hline 53 & 1 & 1001 & 119 & 0 & 1046 & 0 & 0 & 12 & 140 & 0 & 232 & 1073 \\
\hline 54 & 0 & 14 & 346 & 0 & 755 & 0 & 0 & 0 & 27 & 0 & 114 & 613 \\
\hline 55 & 0 & 3801 & 465 & 49 & 4006 & 0 & 4 & 0 & 251 & 0 & 858 & 4084 \\
\hline 56 & 0 & 60 & 57 & 6 & 654 & 0 & 0 & 0 & 0 & 0 & 78 & 486 \\
\hline 57 & 0 & 28 & 336 & 0 & 1213 & 0 & 0 & 0 & 0 & 0 & 158 & 928 \\
\hline 58 & 0 & 1 & 285 & 0 & 1593 & 0 & 0 & 0 & 0 & 144 & 202 & 1198 \\
\hline 59 & 17 & 0 & 184 & 0 & 2132 & 87 & 28 & 0 & 0 & 38 & 249 & 1577 \\
\hline 60 & 10 & 166 & 0 & 0 & 536 & 0 & 13 & 0 & 121 & 0 & 85 & 423 \\
\hline 61 & 1 & 1217 & 152 & 0 & 350 & 0 & 0 & 17 & 200 & 6 & 194 & 951 \\
\hline 62 & 0 & 501 & 68 & 2 & 784 & 0 & 0 & 0 & 306 & 324 & 199 & 746 \\
\hline 63 & 0 & 162 & 0 & 0 & 590 & 0 & 0 & 0 & 59 & 0 & 81 & 454 \\
\hline 64 & 2 & 21 & 152 & 0 & 1234 & 0 & 0 & 0 & 4 & 21 & 143 & 915 \\
\hline 65 & 6 & 0 & 74 & 2 & 1442 & 0 & 12 & 0 & 5 & 0 & 154 & 1060 \\
\hline 66 & 2 & 39 & 4 & 0 & 5235 & 0 & 4 & 0 & 0 & 64 & 535 & 3838 \\
\hline 67 & 17 & 9450 & 8745 & 2722 & 18077 & 7441 & 11458 & 5385 & 241 & 7549 & 7109 & 18009 \\
\hline 68 & 582 & 209 & 407 & 0 & 488 & 0 & 0 & 0 & 633 & 0 & 232 & 769 \\
\hline 69 & 116 & 726 & 22 & 82 & 1261 & 0 & 0 & 0 & 523 & 85 & 282 & 1132 \\
\hline 70 & 15 & 177 & 0 & 281 & 85 & 0 & 0 & 0 & 57 & 2 & 62 & 254 \\
\hline 71 & 1 & 62 & 21 & 0 & 65 & 0 & 0 & 0 & 261 & 0 & 41 & 204 \\
\hline 72 & 0 & 273 & 0 & 0 & 306 & 0 & 0 & 0 & 42 & 0 & 62 & 304 \\
\hline 73 & 80 & 23 & 14 & 0 & 1017 & 75 & 0 & 0 & 0 & 0 & 121 & 754 \\
\hline 74 & 16 & 0 & 0 & 0 & 85 & 0 & 0 & 0 & 0 & 41 & 14 & 71 \\
\hline 75 & 1650 & 6 & 1059 & 26 & 455 & 1113 & 1475 & 69 & 0 & 3792 & 965 & 3326 \\
\hline 76 & -186 & -178 & 267 & 0 & 1227 & 0 & 0 & 0 & 47 & 1 & 118 & 936 \\
\hline 77 & 279 & 294 & 7 & 0 & 26 & 22 & 0 & 0 & 446 & 0 & 107 & 440 \\
\hline 78 & 14 & 443 & 0 & 0 & 72 & 0 & 38 & 17 & 691 & 0 & 128 & 607 \\
\hline 79 & 2 & 84 & 3 & 0 & 612 & 0 & 0 & 21 & 457 & 0 & 118 & 566 \\
\hline 80 & 345 & 1752 & 904 & 2625 & 1894 & 5532 & 2065 & 1122 & 10422 & 3957 & 3062 & 9067 \\
\hline 81 & 3810 & 239 & 153 & 0 & 802 & 0 & 0 & 0 & 118 & 0 & 512 & 2881 \\
\hline 82 & 1423 & 333 & 855 & 0 & 657 & 0 & 0 & 0 & 716 & 0 & 398 & 1393 \\
\hline 83 & 1237 & 324 & 410 & 0 & 400 & 0 & 0 & 0 & 262 & 0 & 263 & 1035 \\
\hline 84 & 229 & 67 & 98 & 443 & 584 & 0 & 121 & 236 & 144 & 0 & 192 & 573 \\
\hline 85 & 38 & 13 & 0 & 1 & 778 & 0 & 3 & 0 & 448 & 0 & 128 & 663 \\
\hline 86 & 4422 & 2490 & 945 & 413 & 931 & 0 & 12 & 734 & 1141 & 4 & 1109 & 3876 \\
\hline 87 & 1258 & 246 & 106 & 26 & 798 & 0 & 80 & 7 & 118 & 0 & 264 & 1111 \\
\hline
\end{tabular}


TABle 3: Continued.

\begin{tabular}{|c|c|c|c|c|c|c|c|c|c|c|c|c|}
\hline \multirow{2}{*}{ Spot on Chip ${ }^{(a)}$} & \multicolumn{10}{|c|}{ Case Number ${ }^{(\mathrm{b})}$ and Gene Expression Level ${ }^{(\mathrm{c})}$} & \multirow{2}{*}{ Mean $^{(d)}$} & \multirow{2}{*}{ Mean $+2 \mathrm{SD}^{(\mathrm{e})}$} \\
\hline & 6 & 15 & 20 & 27 & 31 & 38 & 40 & 41 & 50 & 54 & & \\
\hline 88 & 701 & 99 & 247 & 152 & 122 & 0 & 7 & 0 & 343 & 0 & 167 & 609 \\
\hline 89 & 1710 & 108 & 94 & 89 & 1045 & 0 & 0 & 138 & 341 & 0 & 353 & 1495 \\
\hline $90 \mathrm{r}$ & 1649 & 1917 & 1637 & 25454 & 5125 & 12036 & 16692 & 16458 & 31646 & 7670 & 12028 & 33016 \\
\hline
\end{tabular}

(a) The 172-kbp EBV genome was PCR-amplified to produce 71 consecutive DNA fragments that were subsequently fabricated onto EBV-chip. These viral DNA fragments were given Arabic numbers, except for the internal W-repeated region (as R), as indicated at the left and their residing genes were cited in Figure 1.

(b) Ten oral cancer specimens shown here are determined to be EBV-negative by the criteria described in the Materials and Methods Section, and the numbers correspond to the patient number shown in Table 1.

(c) The gene expression levels were represented as the arbitrary numbers of hybridization signals (blue-spots on EBV-chips) digitalized by ScanAlyze program [32]. Owing to the highly sensitive tyramide-biotin signal amplification method, some spots on the EBV-chips hybridized to the cDNA samples from the EBV-negative tissues still revealed viral gene expression signals, which were considered as the background signals.

(d) Mean values with their standard deviations (SDs) of the background gene expression levels for all spots were calculated.

(e) The values of means plus two-time SD were obtained as the threshold expression levels for calculating the viral gene expression levels in EBV-positive tissue samples (Figure 2).

the viral and control gene spots is shown in Figure 1(a). Hybridization was performed with total RNA that had been isolated from tissue biopsies and pretreated with RQ RNasefree DNase (Promega, Madison, WI, USA), followed by the conversion of RNA to biotin-labeled cDNA in a reaction mixture containing $0.5 \mu \mathrm{g}$ of total RNA, in vitro transcribed mRNA of bacteriophage lambda DNA (1.1 and $1.2 \mathrm{kbp}$ Pst $\mathrm{I}$ digested DNA with the amounts of $0.2 \mathrm{ng}$ and $0.4 \mathrm{ng}$, resp.) and two plant genes ( $r b c L, 1 \mathrm{ng}$ and $r c a, 5 \mathrm{ng}$ ), $3 \mu \mathrm{g}$ random hexamers, $3 \mu \mathrm{g}$ oligo-dT primers, 200 units of MMLV reverse transcriptase (Promega, Madison, WI, USA), dNTPs, and biotin-16-dUTP (Roche, Mannheim, Germany). The biotinlabeled cDNA samples (or targets) and $1 \mathrm{ng}$ of biotin-labeled plant GA4 gene DNA were hybridized together to the EBV genomic DNA spots (probes) on the chips, followed by three washing steps. Since total RNAs instead of mRNA samples were used, Tyramide Signal Amplification (TSA) Biotin System (PerkinElmer, Boston, MA, USA) was employed to amplify the hybridization signals of the rare mRNA species transcribed from viral genes in cancer cells. Finally, colorimetric detection was performed according to a method described previously [29] by using a mixture containing streptavidin conjugated $\beta$-galactosidase (Roche) and X-gal substrate (Sigma-Aldrich) to produce blue hybridization signals. The EBV-chips were then scanned with a highresolution scanner (UMAX PowerLook 3000, Taipei, Taiwan, ROC). The intensities of the dose were quantified digitally with the ScanAlyze program [32].

To confirm the gene expression patterns, quantitative real-time RT-PCRs on the CD45, $\beta$-actin, EBNA1, and EBNA2 gene transcripts were performed. CD45 is a general surface marker for white blood cells (WBCs) including Bcell, and EBNA1 and EBNA2 are viral genes. For this, $0.8 \mu \mathrm{g}$ of RQ DNase-pretreated total RNAs derived from the tumor samples, which had already tested negative in amplification of $\beta$-actin DNA by a regular PCR procedure, were first converted to cDNA using the protocol described in the microarray experiments, except that biotin-dUTP was replaced by regular dTTP. The cDNA samples were further divided equally into four parts and they were added individually to the tubes containing the PCR reagent mixture (EZtime Real-TimePCR Premix, Yeastern Biotech Co., Taipei, Taiwan, ROC) and the primers and probes for the particular genes. Subsequently, the real-time PCR amplifications were performed by a sequence-detection system (ABI 7500 Fast Real-Time PCR System, Applied Biosystems, Foster City, CA, USA) with conditions specified earlier [33]. The primers and probes for the CD45 and $\beta$-actin genes, with the reporter dye FAM (6-carboxy-fluorescein) and the quencher TAMRA (6-carboxy-tetramethyl-rhodamine) attached to the respective $5^{\prime}$ - and $3^{\prime}$-ends of the probes, were synthesized (by MDBio, Inc., Taipei, Taiwan, ROC) according to the previous report [29], whereas the other primer sets and probes were synthesized in the same fashion according to the sequences reported earlier for EBNA1 [34] and EBNA2 [35]. Since the level of $\beta$-actin expression was used as an internal standard, the relative mRNA levels of the target genes in each tumor tissue/cell line were normalized to its own $\beta$-actin mRNA content before comparing among different testing samples. In practice, the quantitative values obtained in the real-time amplification are the thresholds PCR cycle numbers $(\mathrm{Ct})$, where the mRNA level of a target gene is reverse proportional to its $\mathrm{Ct}$, and they were presented as $2^{-\Delta \mathrm{Ct}}$, where $-\Delta \mathrm{Ct}=$ $\mathrm{Ct}_{\text {target gene }}-\mathrm{Ct}_{\beta \text {-actin }}$.

2.3. Statistical Evaluation on Gene Expression and Analysis. EBV-chip hybridization experiments were also designed to identify any viral gene that may be associated with molecular tumorigenesis of oral cancer. The important criterion for such EBV genes to be considered was that the expression of the genes must be either frequently or seldom detected among cancer samples. For this, a measuring formula was set up specifically as follows. Briefly, the threshold expression level (the basal line distinguishing gene expression or not) for every spot on EBV-chip was first calculated by averaging all digital background signals for the same spots on the chips, which had been hybridized to those tumor specimens determined to be EBV-negative, plus twofolds of their standard deviations or SD (Table 3). In this case, there were 71 
numbers for the threshold expression levels corresponding to the same numbers of EBV genomic probes (spots) on EBV-chip. For the EBV-positive samples, actual expression level for each spot on a chip was obtained by subtracting the threshold expression level from the detected arbitrary digital number of that spot. Therefore, the genes that are regarded as expressed should have the actual expression levels larger than zero. The comparative expression levels were then presented as logarithmic values of the actual expression levels that were larger than zero, and again larger numbers indicated greater expression levels.

Fisher's two-tailed Exact Test was employed to analyze the frequencies of the expression of particular viral genes among the studied cancer specimens to associate with the manifestation of the particular clinical characteristics; differences of $P<.05$ were considered significant.

\section{Results}

3.1. EBV Infection Rate. Oral cancer patients who participated voluntarily in the current study consisted of 55 males and 2 females with an age ranging from 26 to 79 (Table 1). They were diagnosed with malignant SCC manifesting exophytic, ulcerative, or deep invasive lesions; 20 of them were found to have multiple tumor lesions at the time of first clinical examination or at the followup postsurgical excisions of the primary cancer tissues. Only the tissue removed from the primary cancer site of each patient was included in the subsequent experiments. Since EBV-chip hybridization detects multiple viral gene transcripts and has been demonstrated to be accurate in detecting EBV infection [29], the cancer specimens were subjected directly to EBV-chip hybridization without prior PCR determination. As the controls, total RNA from EBVfree U937 monocytic cell line and B95-8 and P3HR1 B cell lines were extracted and converted to biotin-cDNA, followed by EBV-chip hybridization in parallel (Figure 1(b)). The results of the control experiments were as expected and consistent with those reported previously [29], thus confirming the reliability of the method. In the present study, 57 tissue specimens were subjected to EBV-chip hybridization to determine which cancer samples had been infected with the virus. Microarray hybridization was always performed up to three times until the control DNA probes exhibited consistent and reproducible hybridization signals, and the best EBV-chip hybridization result from each cancer sample was selected for further analysis. According to the criteria set previously [29], those cancer cDNAs that hybridized and yielded low or no signals at most spots, including that containing the EBNA1 gene, on EBVchips were considered as EBV-negative, whereas the EBVpositive cancer tissues always produced patterns consisting of multiple spots with dark hybridization signals. After EBV-chip hybridization, a total of 10 cancer tissues was determined to be negative in EBV infection because their cDNA did not hybridize to viral gene spots (Figure 1(c)). Notably, many spots on the chips hybridized with RNA from EBV-negative tumor tissues showed low arbitrary numbers after digitalization (Table 3 ), which were due to tyramide-biotin-mediated signal amplification and sensitive colorimetric scanning/digitalization; these numbers were regarded as background signals. On the other hand, tumors from 47 patients who had OSCC were found EBV-positive; two representative EBV-chip images derived from the EBVpositive biopsies are shown in Figure $1(\mathrm{~d})$. In conclusion, this study found a relatively high EBV prevalent rate (47/57 or $82.5 \%)$ in the patient group, higher than the results reported by other investigations conducted in recent years, which mainly performed PCR-based detection [15-26].

3.2. Expression of EBV Genes in Cancer Samples. To analyze the patterns of viral gene expression in the EBV-positive cancer samples, this study first used the background signals of $10 \mathrm{EBV}$-negative cancer tissues to determine the threshold expression levels for every viral gene spots (71) on EBVchip (Table 3). For the given viral genes on EBV-chip that were considered to be expressed, their arbitrary digital signals, which were derived from hybridization with the particular EBV-positive cancer cDNA, must be greater than the threshold expression levels for the same spots. Thus, the actual expression levels for the viral genes in the EBVpositive cancer tissues were obtained by subtracting their arbitrary numbers from the threshold expression levels for the respective genes determined in Table 3. Since they were large numbers, the present study used the logarithmic system with the larger log numbers representing the greater expression levels (Figure 2). Owing to highly sensitive signal amplification and colorimetric scanning/digitalization methods, most expressed viral genes had the expression levels larger than $\log 3$, and approximately half of them reached $\log 4$ levels.

As a result of this calculation, the frequency of viral gene expression could be indicated by the number of cancer specimens among the $47 \mathrm{EBV}$-positive OSCC showing positive expression levels. Although the expression of the EBNA1 gene has been used as the indicator of EBV infection, in the present study, the EBNA1 transcript was not detected in all of the 47 specimens, probably due to the scarcity of the mRNA. Instead, we detected seven spots (the spotted DNA may contain one or more genes/open reading frames or ORFs as indicated in Figure 1(a)) whose residing genes/ORFs expressed mRNA in $85 \%$ (>40 samples) of cancer biopsies (Figure 2), and these spots were numbers 1 (terminal proteins, LMP2A, and 2B), 6 (W-repeated region), 35 (large tegument protein), 44 (BMRF2), 52 (EBNA3B and 3C), 75 (gp85), and the spot $\mathrm{R}$ or the $\mathrm{W}$-repeated region (BWRF1). Ten additional spots expressed mRNA in 75\% (>35 samples) of the specimens, which encoded envelope proteins, enzymes, and potential regulatory proteins such as membrane antigen $\mathrm{p} 140$, glycoprotein $\mathrm{M}$, gp150, primaseassociated factor, vIL-10, and others. Thus, it seemed that EBV in three quarters of cancer tissues examined in the present study expressed proteins mainly for maintaining the levels of the virus structural proteins and latency. On the other hand, only three spots were expressed in less than $10 \%$ ( $<5$ biopsies) of cancer tissues shown in Figure 2, and 


\begin{tabular}{|c|c|c|c|c|c|c|c|c|c|c|c|}
\hline $\begin{array}{c}\lambda-1.2 \\
\text { DNA }\end{array}$ & RbcL & HAT22 & dye & \begin{tabular}{|l|}
36. \\
BPLF1
\end{tabular} & \begin{tabular}{|l|}
44. \\
BMRF2
\end{tabular} & \begin{tabular}{|l|}
52. \\
BERF2a \\
BERF3
\end{tabular} & \begin{tabular}{|l}
60. \\
BBLF4 \\
BBRF1
\end{tabular} & \begin{tabular}{|l|}
68. \\
BDLF4 \\
BDRF1
\end{tabular} & \begin{tabular}{|l}
76. \\
BXLF2 \\
BXLF1
\end{tabular} & \begin{tabular}{|l|}
81. \\
BILF1 \\
BALF5
\end{tabular} & \begin{tabular}{|l|}
86. \\
BALF2
\end{tabular} \\
\hline GA4 & GAPDH & $\beta$-actin & dye & $\begin{array}{l}37 . \\
\text { BPLF1 }\end{array}$ & \begin{tabular}{|l|}
45. \\
BMLF1 \\
BSLF2
\end{tabular} & \begin{tabular}{|l|}
53. \\
BERF4
\end{tabular} & \begin{tabular}{|l|} 
61. \\
BBRF1 \\
BBRF2 \\
BBRF3 \\
\end{tabular} & \begin{tabular}{|l|}
69. \\
BDLF3 \\
BDLF2
\end{tabular} & \begin{tabular}{|l|}
77. \\
BXLF1 \\
BXRF1 \\
BVRF1 \\
\end{tabular} & \begin{tabular}{|l|}
82. \\
BALF5 \\
BCRF4
\end{tabular} & \begin{tabular}{|l|} 
87. \\
BALF2 \\
BALF1 \\
BARF1 \\
\end{tabular} \\
\hline $\begin{array}{c}\lambda-1.1 \\
\text { DNA }\end{array}$ & Rca & HAT4 & dye & $\begin{array}{l}38 . \\
\text { BPLF1 }\end{array}$ & $\begin{array}{l}46 . \\
\text { BSLF1 }\end{array}$ & \begin{tabular}{|l|} 
54. \\
BERF4 \\
BZLE2 \\
BZLF1
\end{tabular} & \begin{tabular}{|l|} 
62. \\
BBRF3 \\
BBLF2
\end{tabular} & $\begin{array}{l}\text { 70. } \\
\text { BDLF2, } \\
\text { BDLF1, } \\
\text { BcLF1 }\end{array}$ & \begin{tabular}{|l|}
78. \\
BVRF1 \\
BVRF2
\end{tabular} & $\begin{array}{l}83 . \\
\text { BALF4 }\end{array}$ & $\begin{array}{l}88 . \\
\text { BNLF2a } \\
2 \mathrm{~b}\end{array}$ \\
\hline ASA1 & APS1 & LhcI & dye & \begin{tabular}{|l|}
39. \\
BOLF1
\end{tabular} & \begin{tabular}{|l|}
47. \\
BSRF1 \\
BLLF3 \\
BLRF1 \\
\end{tabular} & \begin{tabular}{|l}
55. \\
BRLF1
\end{tabular} & \begin{tabular}{|l|}
63. \\
BBRF3
\end{tabular} & $\begin{array}{l}71 . \\
\text { BcLF1 }\end{array}$ & \begin{tabular}{|l}
79. \\
BdRF1 \\
BILF2
\end{tabular} & \begin{tabular}{|l|}
84. \\
BALF4 \\
BARF0 \\
BALF3
\end{tabular} & \begin{tabular}{|l}
89. \\
BNLF1
\end{tabular} \\
\hline $\begin{array}{l}1 . \\
\text { Term. } \\
\text { proteins }\end{array}$ & $\begin{array}{l}5 . \\
\text { BCRF1 }\end{array}$ & $\begin{array}{l}28 . \\
\text { BHLF1 }\end{array}$ & \begin{tabular}{|l|}
32. \\
BFLF2 \\
BFLF1
\end{tabular} & $\begin{array}{l}40 . \\
\text { BOLF1 }\end{array}$ & $\begin{array}{l}48 . \\
\text { BLLF2 } \\
\text { BLLF1 }\end{array}$ & \begin{tabular}{|l|}
56. \\
BRRF1 \\
BRRF2
\end{tabular} & \begin{tabular}{|l} 
64. \\
BBLF1 \\
BGLF5 \\
BGLF4 \\
\end{tabular} & $\begin{array}{l}72 . \\
\text { BcLF1 }\end{array}$ & $\begin{array}{l}80 . \\
\text { BILF1 }\end{array}$ & $\begin{array}{l}85 . \\
\text { BARF0 } \\
\text { BALF3 } \\
\text { BALF2 }\end{array}$ & $90 \mathrm{r}$. \\
\hline $\begin{array}{l}. \\
\text { BNRF1 }\end{array}$ & \begin{tabular}{|l|}
6. \\
BWRF1
\end{tabular} & $\begin{array}{l}29 . \\
\text { oriLyt }\end{array}$ & \begin{tabular}{|l|}
33. \\
BFRF1 \\
BFRF2
\end{tabular} & $\begin{array}{l}41 . \\
\text { BORF1 }\end{array}$ & $\begin{array}{l}49 . \\
\text { BLLF3 }\end{array}$ & \begin{tabular}{|l|}
57. \\
BRRF2 \\
BKRF1
\end{tabular} & \begin{tabular}{|l|}
65. \\
BGLF4 \\
BGLF3 \\
BGRF1 \\
\end{tabular} & \begin{tabular}{|l}
73. \\
BcLF1 \\
BcRF1
\end{tabular} & & & \\
\hline $\begin{array}{l}3 . \\
\text { BNRF1 }\end{array}$ & $\begin{array}{l}\text { R. } \\
\text { BWRF1 }\end{array}$ & $\begin{array}{l}30 . \\
\text { BHRF1 }\end{array}$ & \begin{tabular}{|l|}
34. \\
BFRF3
\end{tabular} & \begin{tabular}{|l}
42. \\
BORF2
\end{tabular} & $\begin{array}{l}50 . \\
\text { BERF1 }\end{array}$ & \begin{tabular}{|l|}
58. \\
BKRF2 \\
BKRF3
\end{tabular} & \begin{tabular}{|l}
66. \\
BGRF1 \\
BGRF2
\end{tabular} & \begin{tabular}{|l|}
74. \\
BcRF1 \\
BTRF1
\end{tabular} & & & \\
\hline $\begin{array}{l}. \\
\text { EBERs } \\
\text { oriP }\end{array}$ & $\begin{array}{l}27 . \\
\text { BYRF1 }\end{array}$ & \begin{tabular}{|l|}
31. \\
BFLF2
\end{tabular} & \begin{tabular}{|l}
35. \\
BPLF1
\end{tabular} & \begin{tabular}{|l|}
43. \\
BaRF1 \\
BMRF1
\end{tabular} & $\begin{array}{l}51 . \\
\text { BERF2a } \\
\text { 2b }\end{array}$ & \begin{tabular}{|l|}
59. \\
BKRF4 \\
BBLF4
\end{tabular} & $\begin{array}{l}67 . \\
\text { BGLF1 } \\
\text { BDLF4 }\end{array}$ & \begin{tabular}{|l|}
75. \\
BXLF2
\end{tabular} & & & \\
\hline
\end{tabular}

(a)
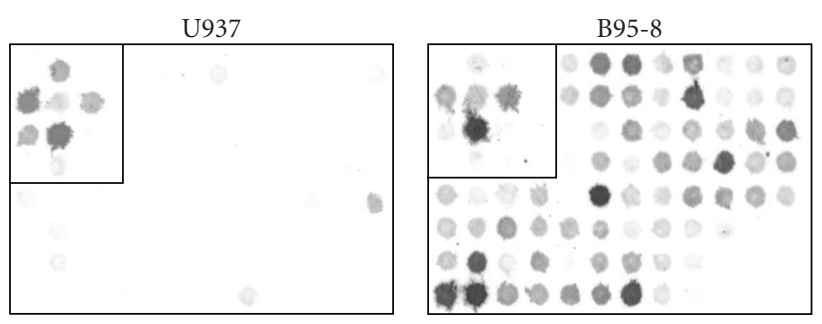

P3HR1 (-)

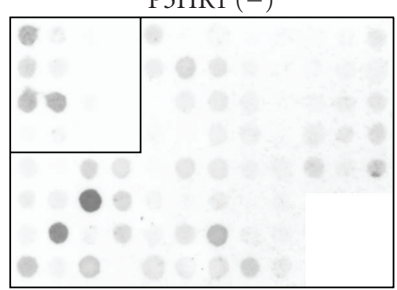

P3HR1 (+)

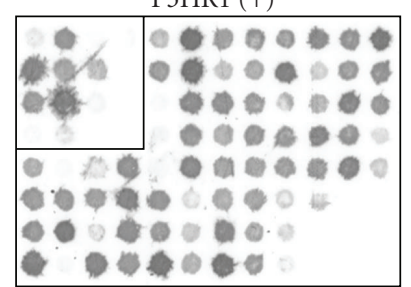

(b)
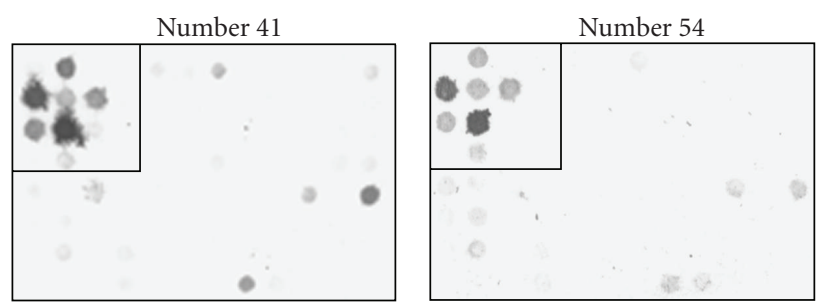

(c)

Number 9
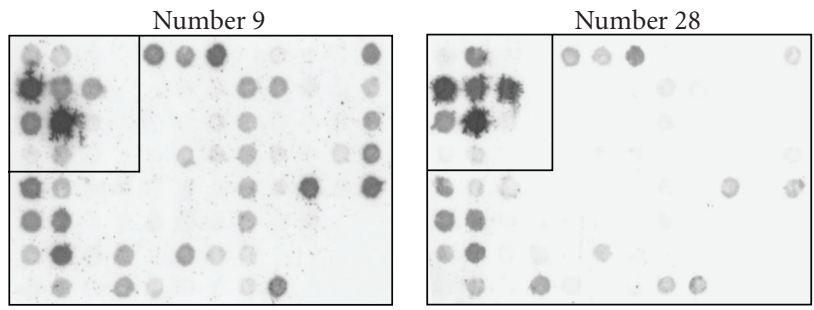

(d)

FIgURE 1: Production of EBV-chip for hybridizing with cDNA samples derived from OSCC biopsies. (a) 16 control and 71 EBV DNA fragments were organized into an 8-row by 12-column format with the size of $4.2 \times 2.4 \mathrm{~mm}$, as specified in the previous report [29]. The controls are located at the upper left corner included in the square box, where it contains 12 DNA fragments for 1.2 and $1.1 \mathrm{kbp}$ Pst Idigested-lambda bacteriophage DNA, plant APS1, ASA1, GA4, HAT4, HAT22, LhcI, RbcL, and Rca genes, and human GAPDH and $\beta$-actin genes. In addition, there were four dye spots that served as the negative controls. Outside the control region, 71 EBV DNA spots, with the gene names, covering the entire EBV genome were arranged in a sequential order on EBV-chip, except that spot R was interrupted between Spots 6 and 27. Spots R and 90r contained EBV W- (internal) and terminal-repeated, respectively, sequences. The arrangement of viral DNA on EBV-chip could facilitate identification of expressed genes shown in hybridization images. (b) Total RNA samples were isolated from U937 cell line, EBV-producing B95-8 cell line, and P3HR1 cell line treated without (-) or with TPA and SB to induce the EBV lytic cycle (+), followed by EBV-chip hybridizations. One of each of the representative reproducible images of these hybridization experiments is shown in here, with the control regions boxed. Since U937 cells were EBV-free, no specific signal on EBV-chip spot was detected (the light color in 90r was the nonspecific hybridization signal, as discussed in the Results section). The RNA samples derived from B95-8 and P3HR1 $(+)$ cells contained EBV transcripts, and therefore lots of, if not all, spots showed dark color, whereas a limited number of spots yielded signals when using EBV-latent P3HR1 (-) cDNA in hybridizations. (c) Cases numbers 41 and 54 were among those 10 EBV-negative OSCC tissues, and basically EBV-chip hybridizations of their cDNA samples revealed no expression signal. (d) Two EBV-positive tissues, numbers 9 and 28, contained substantial numbers of EBV transcripts that resulted in many dark spots in EBV-chips. The intensities of the spots were subsequently quantified and subjected to comparative analysis, as shown in Figure 2. 


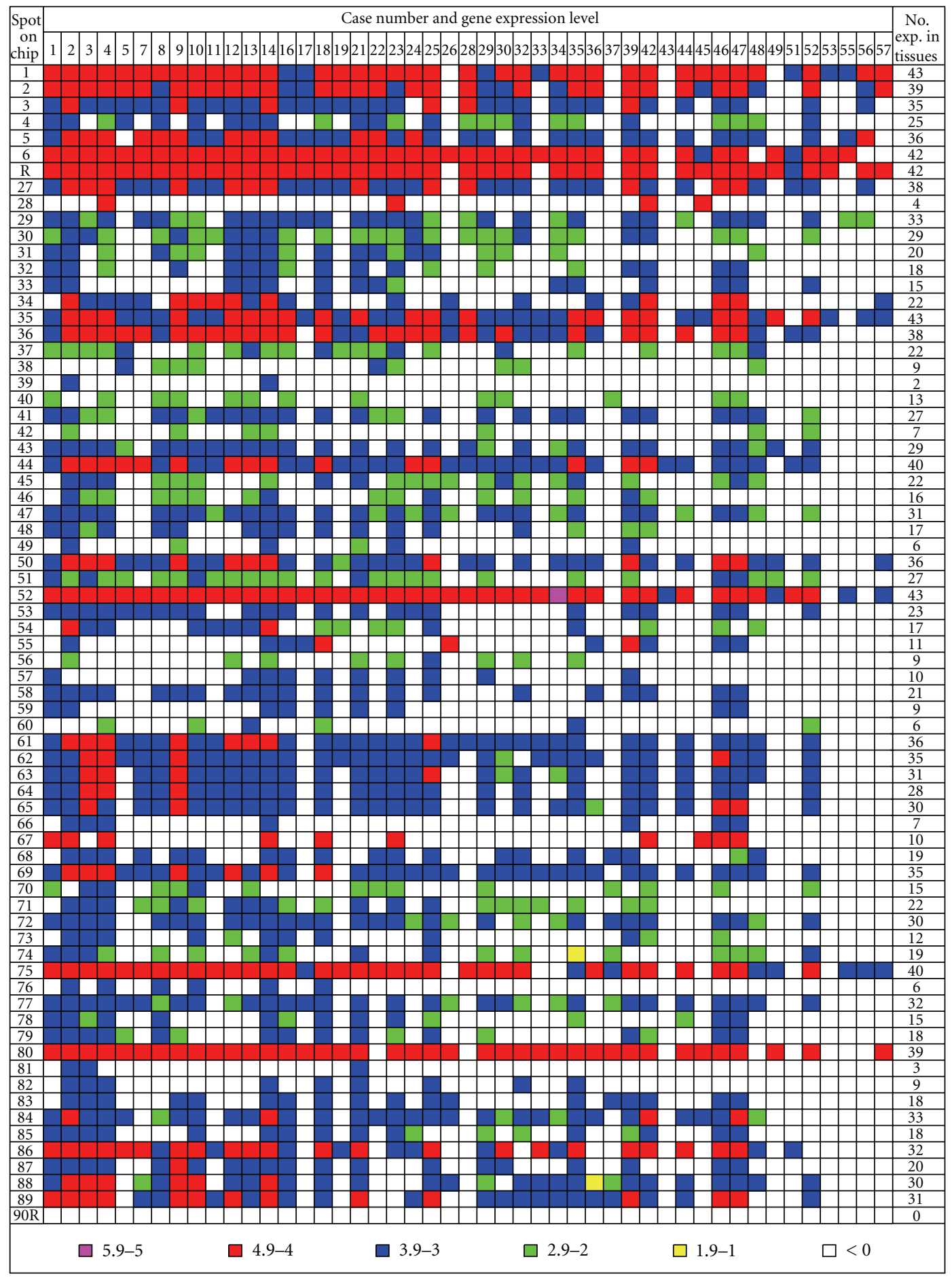

FIGURE 2: Hierarchical presentation of EBV gene expression patterns in forty-seven OSCC specimens. The EBV gene expression patterns in the OSCC tissues were presented by colored codes, as pink, red, blue, green, and yellow squares represented log numbers in the respective ranges of $5.9-5.0,4.9-4.0,3.9-3.0,2.9-2.0,1.9-1.0$, and < 0 , with larger numbers denoting greater expression levels. Among the 47 tissue specimens, the total numbers of samples that expressed the particular viral genes were counted and listed on the left (No. exp. in tissues).

among them numbers 39 (tegument protein) and 81 (DNA polymerase) were relevant to this study; we did not count spot 28 (expressed in 4 biopsies) because it and spots 67 and 90r were found to contain viral sequences similar to some human gene sequences that caused cross-hybridization [29].
The result of a low expression rate for lytic genes (BOLF1, BILF1, and BALF5) in spots 39 and 81 suggested that EBV is not likely to produce large quantity of virons.

To verify the data from microarray experiments, quantitative real-time PCR was undertaken to detect the presence of 
TABLE 4: Statistical association of viral gene expression patterns with cancer manifestations.

\begin{tabular}{|c|c|c|c|c|}
\hline \multicolumn{5}{|c|}{ Analysis of Multiplicity } \\
\hline \multicolumn{5}{|l|}{ Gene Spot 57: $P=.0702$} \\
\hline Lesion & Single & Multiple & \multicolumn{2}{|c|}{ Total } \\
\hline Number Not Expressed & $21(44.68 \%)$ & $16(34.04 \%)$ & \multicolumn{2}{|c|}{$37(78.72 \%)$} \\
\hline Number Expressed & $9(19.15 \%)$ & $1(2.13 \%)$ & \multicolumn{2}{|c|}{$10(21.28 \%)$} \\
\hline Total & $30(63.83 \%)$ & $17(36.17 \%)$ & \multicolumn{2}{|c|}{$47(100 \%)$} \\
\hline \multicolumn{5}{|l|}{ Gene Spot 60: $P=.0737$} \\
\hline Lesion & Single & Multiple & \multicolumn{2}{|c|}{ Total } \\
\hline Number Not Expressed & $24(51.06 \%)$ & $17(36.17 \%)$ & \multicolumn{2}{|c|}{$41(87.23 \%)$} \\
\hline Number Expressed & $6(12.77 \%)$ & $0(0.00 \%)$ & \multicolumn{2}{|c|}{$6(12.77 \%)$} \\
\hline Total & $30(63.83 \%)$ & $17(36.17 \%)$ & \multicolumn{2}{|c|}{$47(100 \%)$} \\
\hline \multicolumn{5}{|c|}{ Analysis of Cancer Types } \\
\hline \multicolumn{5}{|l|}{ Gene Spot 61: $P=.0265$} \\
\hline Cancer types & Deep invasive & Exophytic & Ulcerative & Total \\
\hline Number Not Expressed & $4(8.51 \%)$ & $6(12.77 \%)$ & $1(2.13 \%)$ & $11(23.40 \%)$ \\
\hline Number Expressed & $3(6.38 \%)$ & $18(38.30 \%)$ & $15(31.91 \%)$ & $36(76.60 \%)$ \\
\hline Total & $7(14.89 \%)$ & $24(51.06 \%)$ & $16(34.04 \%)$ & $47(100 \%)$ \\
\hline \multicolumn{5}{|l|}{ Gene Spot 68: $P=.0141$} \\
\hline Cancer types & Deep invasive & Exophytic & Ulcerative & Total \\
\hline Number Not Expressed & $7(14.89 \%)$ & $15(31.91 \%)$ & $6(12.77 \%)$ & $28(59.57 \%)$ \\
\hline Number Expressed & $0(0.00 \%)$ & $9(19.15 \%)$ & $10(21.28 \%)$ & $19(40.43 \%)$ \\
\hline Total & $7(14.89 \%)$ & $24(51.06 \%)$ & $16(34.04 \%)$ & $47(100 \%)$ \\
\hline
\end{tabular}

The clinical manifestations of oral cancer (Table 1) were correlated with the chip-hybridization results of EBV-positive samples (Figure 2). The statistical analysis method used in the present study is Fisher's Exact Test and two-tailed.

viral EBNA1 (BKRF1) and EBNA2 (BYRF1) gene transcripts (Figure 3). In this study, we detect that the mRNA levels for CD45, a pan-WBC surface protein, in all cancer samples are low, suggesting that there is no infiltrated blood cells carrying EBV, which might expressed mRNA in tumors that could cause false positive detection of EBV in microarray analysis. Furthermore, neither the expression of the EBNA1 and EBNA2 gene was detected in either cancer tissue determined to be EBV-negative (Case numbers 38 and 41, Table 3), whereas among the EBV-positive specimens, numbers 2 and 47 only expressed EBNA2 but not EBNA1 mRNA , but numbers 13,14 , and 21 samples yielded strong expression signals for both the vial genes. The results of the quantitative real-time RT-PCR analysis (Figure 3) are therefore consistent with those derived from the microarray experiments (Figure 2).

\subsection{Association of Gene Expression with Clinical Character-} istics. Upon admission to hospital, patients with oral cancers were subjected to careful examinations before surgical procedures and then followed up for four years (Table 1). We recorded multiplicity, site, type, color, and touching sensation of every OSCC (the summary of the former three items are shown in Table 2), and the clinical characteristics of the samples and their viral gene expression patterns were under statistical analysis with the Fisher's Exact Test. The present study did not find any association between the clinical manifestation in multiplicity, site, color, or touching sensation of cancer lesions and the expression of any gene spot (data not shown). However, there were tendencies (Table 4), but did not reach significant levels, that spots 57 (BRRF2 and BKRF1) and 60 (BBLF4 and BBRF1) were expressed in fewer number of cancer specimens isolated from patients manifesting multiple tumor lesions $(P=.0702$ and .0737 , resp.). Since the gene product of BKRF1 (EBNA1) is required for maintaining latent EBV genome and BBLF4 (helicase) is needed in a large amount during the reactivation of viral replication, it seems that the expression of these proteins is not in favor of forming multiple tumor lesions in the same oral cavities, and the spread of EBV would have only happened in close proximity as if the virus plays a role in tumorigenesis. However, the functions of BRRF2 and BBRF1 are not known and their roles could not be coincidently considered in this study. Notably, we did detect two genes whose expression patterns were associated with the lesion types of the cancer in the studied patients. As seen in Table 4, the distributive frequencies of expressing spot 61, which contained BBRF1 (capsid protein), BBRF2 (hypothetical protein), and BBRF3 (glycoprotein M), and spot 68, which contained BDLF4 (hypothetical protein) and BDRF1 (capsid antigen) were both significantly greater in OSCC exhibiting exophytic and ulcerative lesions than those tissues with deep invasion $(P=.0265$ and $P=.0141$ for spots 61 and 68 , resp.). The data suggested that the expression of viral structural proteins, the event that occurs 


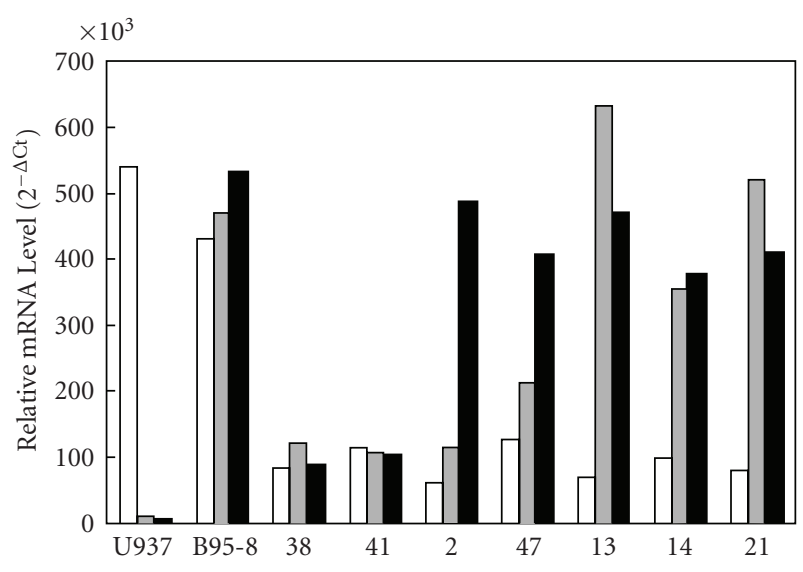

FIGURE 3: Quantitative real-time RT-PCR of the CD45, EBNA1, and EBNA2 transcripts in tumor samples. Due to the limited number of available frozen tissues, seven OSCC samples numbered 38, 41, 2, 47, 13, 14, and 21 (Case numbers are as those listed in Table 1), with the former two categorized as EBV-negative and others as positive, are used in this quantitative real-time PCR experiment. The portions in the frozen tissues applying to the experiments were all at positions adjacent to the respective tissue specimens used in the prior EBV-chip hybridizations. The results reveal that, after normalizing with the expression levels for the $\beta$-actin gene, the expressions of the gene for the pan-WBC surface marker CD45 in both the cell lines U937 and B95-8 are clearly detected, whereas they are low in all cancer samples, suggesting that EBV gene expression, if any, present in infiltrated blood cells does not contribute to the signals detected with EBV-chip. Tumor sample numbers 38 and 41 are EBV-negative (Table 3), samples 2 and 47 only express the great amounts of the EBNA2 gene transcript, and the rest of cases numbered 13, 14, and 21 have the strong expression signals for both the EBNA1 and EBNA2 genes. In conclusion, the data from the quantitative real-time RT-PCR analysis are in agreement with those shown in Figure 2. In here, two identical quantitative real-time PCR have been performed and very similar results are obtained. $\square$ : CD45; $\square$ : EBNA1; $\square$ : EBNA2.

during lytic viral replication, has potential effect on muscle invasion. Despite obtaining this molecular epidemiologic result, further pathologic investigations will be needed to clarify their aggressive roles in cancer development.

\section{Discussion}

In this molecular epidemiologic study, the newly developed EBV-chip is employed to determine the EBV prevalent rate and viral gene expression patterns in 57 OSCC biopsies from patients in Taiwan. By EBV-chip hybridization, a high EBV prevalent rate of $82.5 \%(47 / 57)$ was detected, which was greater than that in all previous investigations on OSCC reported worldwide in the past decade. Because microarray technique employs no nucleic acid amplification (PCR) procedure, which is likely to amplify EBV genome present in reservoir lymphocytes infiltrated in tumor sites (bystander $\mathrm{B}$ cells), and it hybridizes only to viral gene transcripts with a sufficient sensitivity, the detected prevalent rate should be reliable, and the result of the CD45 mRNA quantitation shown in Figure 3 supports this conclusion. For a large virus like EBV, which is only a portion of its sequence coding for genes with known functions, it is possible that, due to infrequent expression or the transcript is too small, common molecular methods employed in previous studies may not have identified all viral genes/coding regions. Therefore, the use of genome-chip, instead of viral cDNA-chip, has another advantage of facilitating the discovery of cryptic viral gene expression, which may only be expressed at the particular timeframe and/or tissues, in the well-designed experiments. Furthermore, EBV-chip is capable of examining all viral mRNA species simultaneously, but not just only one or a few gene transcripts by reverse transcription- (RT-) PCR. However, to limit the size and effective production of EBVchip, more than two thirds of viral DNA fragments or spots contained more than one genes/ORFs (Figure 1(a)). This design facilitated a fast scanning of the entire viral genome by a large number of samples of interest to profile the global gene expression patterns. Upon detecting the gene expression signal, such as those in spots 61 and 68 described above, further molecular analyses can subsequently be employed to characterize every detected gene/ORF in detail. Therefore, with a single relayed procedure of RNA isolation, reverse transcription, and hybridization, the entire EBV genomic DNA can be scanned thoroughly for gene expression levels. In this way, all potential viral gene expression involved in tumorigenesis can be effectively detected, analyzed, and correlated with clinical properties of the studied tumor.

The high EBV infection rate $(82.5 \%)$ detected in the studied OSCC has been subjected to confirmation by the EBER in situ hybridization procedure (data not shown), but the EBER was not an indicative marker in the current and previous reports $[17,20,26,27]$, as it is in NPC [4]. Notably, a recent investigation [23], which studied OSCC patients admitted to hospital between 1996 and 2000 in Okinawa, Japan, also demonstrated a very high EBV infection rate (72\%) obtained by nucleotide sequence analysis, and this result was consistent with the data $(>75 \%)$ from earlier reports studying other Japanese populations [18, 22]. Since Okinawa as well as the main islands of Japan is in a short distance north of Taiwan, the two ethnic groups share similar genetics, cultures, and diets, and these reports and the current study were conducted molecular surveys in close time periods, the coincident detection of the high EBV prevalent rates in both studies suggested the possibility of an epidemiologic link between the virus and oral cancer in the populations residing in the region. Moreover, because EBV is an infectious agent and likely to spread, the detection of high viral prevalent rate and the multiple lesions (17/47, Tables 1 and 2) present in the studied OSCC patients are consistent with the concept of field cancerization of the head and neck [36]; yet more studies are required to confirm the hypothesis.

To analyze and compare effectively the complex gene expression patterns among the studied OSCC specimens, this study formulated and calculated the expression thresholds for all 71 EBV DNA spots from their mean expression level in the $10 \mathrm{EBV}$-negative cancer tumors, and any spots in the EBV-positive specimens that were regarded as expressed had to have an expression level larger than its respective 
expression threshold. By doing so, the numbers and types of genes/ORFs that are expressed in the particular OSCC sample can be determined for association investigations. In the present study, the vast majority of EBV-positive cancer (47 cases) expressed both latent and lytic viral gene transcripts. Viral proteins associated with the viron, such as BMRF2 glycoprotein, terminal proteins, large tegument protein, gp85, p140, gpM, and gp150, and latency, such as EBNA2, EBNA3A, EBNA3B, and EBNA3C, are expressed in three-quarters of EBV-positive cancer tissues collected in the current investigation (Figure 2). These results were not unexpected as EBV tends to have latent infection in B cells but productive replication in epithelial cells $[3,5]$, and yet the virus also has to maintain a certain level of latency in transformed epithelium. Since the expression of the viral genes for EBNA2 and EBNA3s is seldom reported in epithelial cancers, a double-nested RT-PCR procedure [37] (data not shown), as well as quantitative real-time RT-PCR (Figure 3), is used and confirmed the presence of the mRNA species in a limited number of the studied tissues that were available at the time. However, this discrepancy needs to be further clarified by examining more OSCC tissues with the most sensitive and feasible PCR protocols (e.g., qPCR) and primer sets for all noted genes. Moreover, among highly expressed viral proteins, BMRF2 glycoprotein (spot 44, expressed in 40 OSCC), an early viral protein with nucleotide sequence homologous to human herpesvirus 8, Kaposi's sarcomaassociated herpesvirus, is of particular interest because it is expressed at high levels in hairy leukoplakia and was found to associate with the nuclear chromatin [38]. Recent reports further demonstrated that the glycoprotein interacts with one family of integrins that facilitated virus attachment and subsequent infection in oral epithelial cells, but not in B lymphocytes [39]. In other studies [20, 22], the viral oncogenic protein LMP-1 was frequently detected in EBVpositive OSCC. This finding was consistent with our results that 31 out of $47(66.0 \%)$ cancers expressed mRNA in spot 89. With such high requirement for the structural and surface protein synthesis taken into consideration, the data indicate that EBV is constantly assembling viral particles for infection, and yet, in the meantime, the virus has to maintain latency by expressing many latent gene products. In contrast, the enzymes, such as DNA polymerase (spot 81, expressed only in three biopsies) in the general virus replication machinery and EBNA1 (spot 57, expressed only in 10 OSCC) for maintaining latent viral genome, were not detected in a large number of samples, which may be due to the unnecessary presence of these proteins in great quantities for maintaining adequate genetic materials, and thus their expression levels were too low to be detected by hybridization. The results then suggest that viral replication and maintaining latency are under a delicate balance in mucosal epitheliumderived OSCC, because EBV infection is often productive in epithelial cells [3,9], while the virus is known to maintain latency in many tumor malignancies that include Burkitt's lymphoma (Latency I), Hodgkin's disease, undifferentiated NPC (Latency II), EBV lymphoproliferative diseases, and immunoblastic lymphomas in immunosuppressed patients (Latency III). Therefore, the highly expressed nature of the noted structural viral proteins found in the studied OSCC provides a reasonable rationale to further investigate their roles, directly or indirectly, in the tumorigenesis of the cancer.

Importantly, after statistical analysis of the viral gene expression profiles, this study finds specifically strong association between the expression frequencies of genes/ORFs residing in DNA spots 61 (BBRF1 for capsid protein, BBRF2 [40], and BBRF3 for gpM $[40,41]$ ) and 68 (BDLF4 and BDRF1 for capsid protein [42]) and the clinical manifestations of OSCC. There were significantly more patients with oral cancer exhibiting exophytic and ulcerative lesions that contained EBV expressing the genes in spot $61(P=.0265)$ or in spot $68(P=.0141)$ than those with deep muscle invasive lesion (Table 4). Since deep muscle invasion (migration) is considered to be of more malignant status in clinics, a greater expression of the viron proteins, which indicates the productive replication of EBV, suggests an unfavorable environment for cancerous cell to migrate. However, whether the viral proteins are involved in negative regulation of cell movement remains to be investigated. Interestingly, among the high-expression-rate spots, vIL-10 (spot 5) was the only protein with regulatory function and expressed in 36 (77.0\%) OSCC. IL-10 is previously known as the cytokine synthesis inhibitory factor (CSIF), which is mainly secreted by activated $\mathrm{T}_{\mathrm{H}} 2$ cells to negatively regulate, on one hand, the synthesis of other cytokines like IFN- $\gamma$, IL-2, TNF- $\alpha$, and GM-CSF by $\mathrm{T}_{\mathrm{H}} 1$ cells or macrophages and downregulates class II MHC antigen expression in monocytes to suppress antigen-specific $\mathrm{T}$ cell proliferation [43]. On the other hand, it stimulates proliferation of mast cells and thymocytes and plays a role in B-cell activation, differentiation, and proliferation. Although vIL-10 shares high homology with IL-10 [44], the viral factor possesses only the activity of CSIF, macrophage deactivation, and promotion of B-cell proliferation [43]. Therefore, it is believed that vIL-10 acts as an anti-inflammatory factor in EBV-infected tissues and inhibits the antiviral $\mathrm{T}_{\mathrm{H}} 1 \mathrm{CD} 4 \mathrm{~T}$-cell responses [45] and stimulates EBV-infected B-cell growth for spreads. It is also possible that, as suggested by the current study from which the majority of OSCC specimens were found to express vIL-10, the virus releases the factor for assisting cancerous epithelial cells to escape the protective cellular immunity.

\section{Acknowledgments}

The authors wish to express their gratitude to Shang-Kai Hung and Chin-Li Lu for their excellent technical supports. The second/third and forth/fifth authors contributed equally to this work. This research was supported partly by funds from the Chi-Mei Medical Center (CMFHR 9308) to CYY and CL, the National Science Council (NSC97-2311-B-037003-MY3) and Kaohsiung Medical University (KMU-EM98-1.4) to HWC, and NSC (NSC94-3112-B-182-004) to STL. Current address for Biehuoy Shieh, who and Ching Li contributed efforts equally to this research, is the Department of Pharmaceutical Science, the University of Colorado at Denver and Health Sciences Center, Denver, CO 80262, USA. 


\section{References}

[1] Y. K. Chen, H. C. Huang, L. M. Lin, and C. C. Lin, "Primary oral squamous cell carcinomaFan analysis of 703 cases in southern Taiwan," Oral Oncology, vol. 35, no. 2, pp. 173-179, 1999.

[2] C.-T. Liao, J.T.-C. Chang, H.-M. Wang, et al., "Analysis of risk factors of predictive local tumor control in oral cavity cancer," Annals of Surgical Oncology, vol. 15, no. 3, pp. 915-922, 2008.

[3] N. Raab-Traub, "Epstein-Barr virus in the pathogenesis of NPC," Seminars in Cancer Biology, vol. 12, no. 6, pp. 431-441, 2002.

[4] C.-C. Wang, M.-L. Chen, K.-H. Hsu, et al., "Second malignant tumors in patients with nasopharyngeal carcinoma and their association with Epstein-Barr virus," International Journal of Cancer, vol. 87, no. 2, pp. 228-231, 2000.

[5] L. S. Young and A. B. Rickinson, "Epstein-Barr virus: 40 years on," Nature Reviews Cancer, vol. 4, no. 10, pp. 757-768, 2004.

[6] P. Gazzaniga, R. Vercillo, A. Gradilone, et al., "Prevalence of papillomavirus, Epstein-Barr virus, cytomegalovirus, and herpes simplex virus type 2 in urinary bladder cancer," Journal of Medical Virology, vol. 55, no. 4, pp. 262-267, 1998.

[7] H. Arbach, V. Viglasky, F. Lefeu, et al., "Epstein-Barr virus (EBV) genome and expression in breast cancer tissue: effect of EBV infection of breast cancer cells on resistance to paclitaxel (Taxol)," Journal of Virology, vol. 80, no. 2, pp. 845-853, 2006.

[8] T. Sasagawa, M. Shimakage, M. Nakamura, J. Sakaike, H. Ishikawa, and M. Inoue, "Epstein-Barr virus (EBV) genes expression in cervical intraepithelial neoplasia and invasive cervical cancer: a comparative study with human papillomavirus (HPV) infection," Human Pathology, vol. 31, no. 3, pp. 318-326, 2000.

[9] I. Mladenova and R. Pellicano, "Infectious agents and gastric tumours: an increasing role for Epstein-Barr virus," Panminerva Medica, vol. 45, no. 3, pp. 183-188, 2003.

[10] H. X. Liu, Y. Q. Ding, Y. O. Sun, et al., "Detection of Epstein-Barr virus in human colorectal cancer by in situ hybridazition," Di Yi Jun Yi Da Xue Xue Bao, vol. 22, no. 10, pp. 915-917, 2002.

[11] A. J. Creager, D. M. Maia, and W. K. Funkhouser, "EpsteinBarr virus-associated renal smooth muscle neoplasm: report of a case with review of the literature," Archives of Pathology \& Laboratory Medicine, vol. 122, no. 3, pp. 277-281, 1998.

[12] C. Y. Castro, M. L. Ostrowski, R. Barrios, et al., "Relationship between Epstein-Barr virus and lymphoepithelioma-like carcinoma of the lung: a clinicopathologic study of 6 cases and review of the literature," Human Pathology, vol. 32, no. 8, pp. 863-872, 2001.

[13] F. Shirasaki, K. Taniuchi, T. Matsushita, Y. Hamaguhi, M. Takata, and K. Takehara, "Epstein-Barr virus-associated Tcell lymphoma: a case of eyelid swelling and intramuscular infiltration mimicking dermatomyositis," British Journal of Dermatology, vol. 147, no. 6, pp. 1244-1248, 2002.

[14] K. Y. Lam, C. Y. Lo, D. L. W. Kwong, J. Lee, and G. Srivastava, "Malignant lymphoma of the thyroid: a 30-year clinicopathologic experience and an evaluation of the presence of Epstein-Barr virus," American Journal of Clinical Pathology, vol. 112, no. 2, pp. 263-270, 1999.

[15] J. D’Costa, D. Saranath, V. Sanghvi, and A. R. Mehta, “EpsteinBarr virus in tobacco-induced oral cancers and oral lesions in patients from India," Journal of Oral Pathology \& Medicine, vol. 27, no. 2, pp. 78-82, 1998.

[16] M. González-Moles, J. Gutiérrez, I. Ruiz, J. A. Fernández, M. Rodriguez, and J. Aneiros, "Epstein-Barr virus and oral squamous cell carcinoma in patients without HIV infection: viral detection by polymerase chain reaction," Microbios, vol. 96, no. 383, pp. 23-31, 1998.

[17] I. Kobayashi, K. Shima, I. Saito, et al., "Prevalence of EpsteinBarr virus in oral squamous cell carcinoma," Journal of Pathology, vol. 189, no. 1, pp. 34-39, 1999.

[18] K. Tsuhako, I. Nakazato, J. Miyagi, et al., "Comparative study of oral squamous cell carcinoma in Okinawa, Southern Japan and Sapporo in Hokkaido, Northern Japan; with special reference to human papillomavirus and Epstein-Barr virus infection," Journal of Oral Pathology and Medicine, vol. 29, no. 2, pp. 70-79, 2000.

[19] H.-S. Jang, J.-O. Cho, C.-Y. Yoon, H.-J. Kim, and J.-C. Park, "Demonstration of Epstein-Barr virus in odontogenic and nonodontogenic tumors by the polymerase chain reaction (PCR)," Journal of Oral Pathology \& Medicine, vol. 30, no. 10, pp. 603-610, 2001.

[20] M. A. González-Moles, J. Gutiérrez, M. J. Rodriguez, I. RuizAvila, and A. Rodriguez-Archilla, "Epstein-Barr virus latent membrane protein-1 (LMP-1) expression in oral squamous cell carcinoma," Laryngoscope, vol. 112, no. 3, pp. 482-487, 2002.

[21] L. P. Sand, J. Jalouli, P.-A. Larsson, and J.-M. Hirsch, "Prevalence of Epstein-Barr virus in oral squamous cell carcinoma, oral lichen planus, and normal oral mucosa," Oral Surgery, Oral Medicine, Oral Pathology, Oral Radiology, and Endodontics, vol. 93, no. 5, pp. 586-592, 2002.

[22] M. Shimakage, K. Horii, A. Tempaku, K. Kakudo, T. Shirasaka, and T. Sasagawa, "Association of Epstein-Barr virus with oral cancers," Human Pathology, vol. 33, no. 6, pp. 608-614, 2002.

[23] G. M. Higa, T. Kinjo, and K. Kamiyama, "Epstein-Barr virus (EBV)-related oral squamous cell carcinoma in Okinawa, a subtropical island, in southern Japan — simultaneously infected with human papillomavirus (HPV)," Oral Oncology, vol. 39, no. 4, pp. 405-414, 2006.

[24] J. V. Bagan, Y. Jiménez, J. Murillo, et al., "Epstein-Barr virus in oral proliferative verrucous leukoplakia and squamous cell carcinoma: a preliminary study," Medicina Oral, Patologia Oral y Cirugia Bucal, vol. 13, no. 2, pp. E110-E113, 2008.

[25] N.-M. Tsang, K.-P. Chang, S.-Y. Lin, et al., "Detection of Epstein-Barr virus-derived latent membrane protein-1 gene in various head and neck cancers: is it specific for nasopharygeal carcinoma?" Laryngoscope, vol. 113, no. 6, pp. 1050-1054, 2003.

[26] A. Iamaroon, U. Khemaleelakul, S. Pongsiriwet, and J. Pintong, "Co-expression of p53 and Ki67 and lack of EBV expression in oral squamous cell carcinoma," Journal of Oral Pathology \& Medicine, vol. 33, no. 1, pp. 30-36, 2004.

[27] I. Cruz, A. J. C. Van Den Brule, A. A. T. P. Brink, et al., "No direct role for epstein-barr virus in oral carcinogenesis: a study at the DNA, RNA and protein levels," International Journal of Cancer, vol. 86, no. 3, pp. 356-361, 2000.

[28] E. Ghedin, A. Pumfery, C. de la Fuente, et al., "Use of multi-virus array for the study of human viral and retroviral pathogens: gene expression studies ChIP-chip analysis," Retrovirology, vol. 1, pp. 10-24, 2004.

[29] C. Li, R.-S. Chen, S.-K. Hung, et al., "Detection of EpsteinBarr virus infection and gene expression in human tumors by microarray analysis," Journal of Virological Methods, vol. 133, no. 2, pp. 158-166, 2006.

[30] Y.-F. Chiu, C.-P. Tung, Y.-H. Lee, et al., "A comprehensive library of mutations of Epstein-Barr virus," Journal of General Virology, vol. 88, no. 9, pp. 2463-2472, 2007. 
[31] V. R. Iyer, M. B. Eisen, D. T. Ross, et al., "The transcriptional program in the response of human fibroblasts to serum," Science, vol. 283, no. 5398, pp. 83-87, 1999.

[32] M. B. Eisen, P. T. Spellman, P. O. Brown, and D. Botstein, "Cluster analysis and display of genome-wide expression patterns," Proceedings of the National Academy of Sciences of the United States of America, vol. 95, no. 25, pp. 14863-14868, 1998.

[33] E. Righetti, G. Ballon, L. Ometto, et al., "Dynamics of Epstein-Barr virus in HIV-1-infected subjects on highly active antiretroviral therapy," AIDS, vol. 16, no. 1, pp. 63-73, 2002.

[34] M. Hong, Y. Murai, T. Kutsuna, et al., "Suppression of Epstein-Barr nuclear antigen 1 (EBNA1) by RNA interference inhibits proliferation of EBV-positive Burkitt's lymphoma cells," Journal of Cancer Research and Clinical Oncology, vol. 132, no. 1, pp. 1-8, 2006.

[35] N. Kubota, K. Wada, Y. Ito, et al., "One-step multiplex realtime PCR assay to analyse the latency patterns of Epstein-Barr virus infection," Journal of Virological Methods, vol. 147, no. 1, pp. 26-36, 2008.

[36] P. K. Ha and J. A. Califano, "The molecular biology of mucosal field cancerization of the head and neck," Critical Reviews in Oral Biology \& Medicine, vol. 14, no. 5, pp. 363-369, 2003.

[37] H. Kanegane, F. Wang, and G. Tosato, "Virus-cell interactions in a natural killer-like cell line from a patient with lymphoblastic lymphoma," Blood, vol. 88, no. 12, pp. 4667-4675, 1996.

[38] J. M. Palefsky, M.-E. Peñaranda, L. T. Pierik, et al., "EpsteinBarr virus BMRF-2 and BDLF-3 expression in hairy leukoplakia," Oral Diseases, vol. 3, supplement 1, pp. S171-S176, 1997.

[39] J. Xiao, J. M. Palefsky, R. Herrera, J. Berline, and S. M. Tugizov, "The Epstein-Barr virus BMRF-2 protein facilitates virus attachment to oral epithelial cells," Virology, vol. 370, no. 2, pp. 430-442, 2008.

[40] E. Johannsen, M. Luftig, M. R. Chase, et al., "Proteins of purified Epstein-Barr virus," Proceedings of the National Academy of Sciences of the United States of America, vol. 101, no. 46, pp. 16286-16291, 2004.

[41] C. M. Lake and L. M. Hutt-Fletcher, "Epstein-Barr virus that lacks glycoprotein gN is impaired in assembly and infection," Journal of Virology, vol. 74, no. 23, pp. 11162-11172, 2000.

[42] W. M. J. van Grunsven, E. C. van Heerde, H. J. W. de Haard, W. J. M. Spaan, and J. M. Middeldorp, "Gene mapping and expression of two immunodominant Epstein-Barr virus capsid proteins," Journal of Virology, vol. 67, no. 7, pp. 39083916, 1993.

[43] K. W. Moore, A. O'Garra, R. de Waal Malefyt, P. Vieira, and T. R. Mosmann, "Interleukin-10," Annual Review of Immunology, vol. 11, pp. 165-190, 1993.

[44] P. Vieira, R. de Waal-Malefyt, M. N. Dang, et al., "Isolation and expression of human cytokine synthesis inhibitory factor cDNA clones: homologous to Epstein-Barr virus open reading frame BCRF-1," Proceedings of the National Academy of Sciences of the United States of America, vol. 88, no. 4, pp. 11721176, 1991.

[45] M. T. Bejarano and M. G. Masucci, "Interleukin-10 abrogates the inhibition of Epstein-Barr virus-induced B-cell transformation by memory T-cell responses," Blood, vol. 92, no. 11, pp. 4256-4262, 1998. 


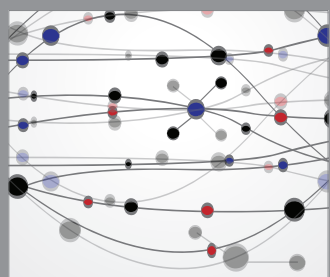

The Scientific World Journal
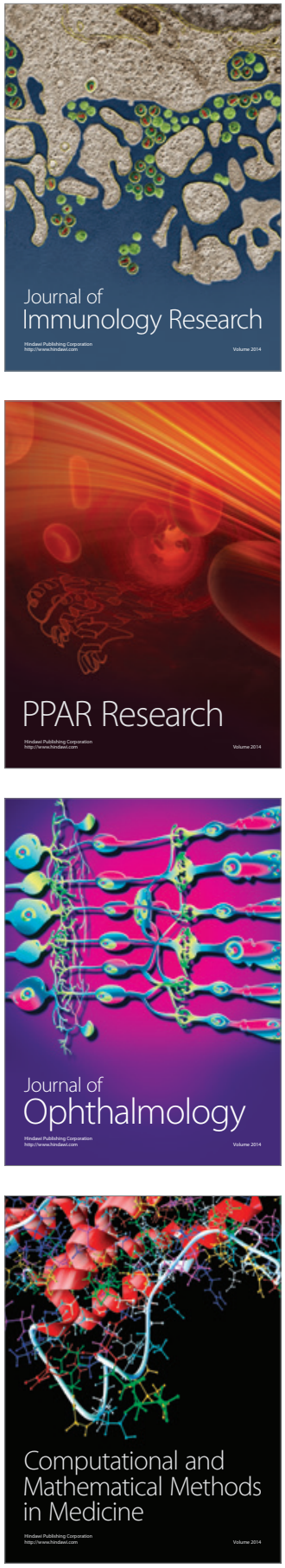

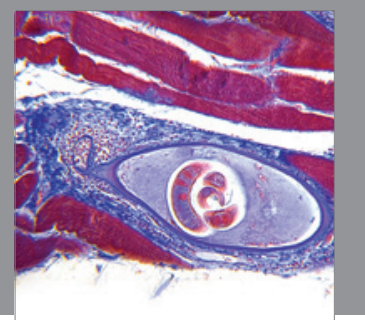

Gastroenterology

Research and Practice
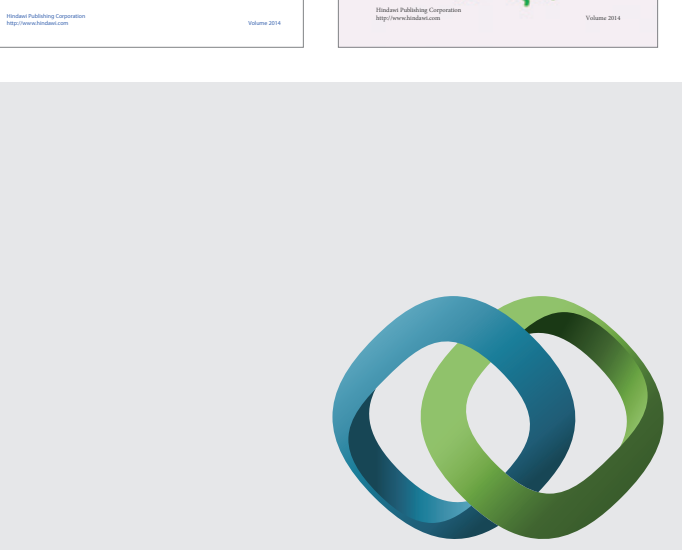

\section{Hindawi}

Submit your manuscripts at

http://www.hindawi.com
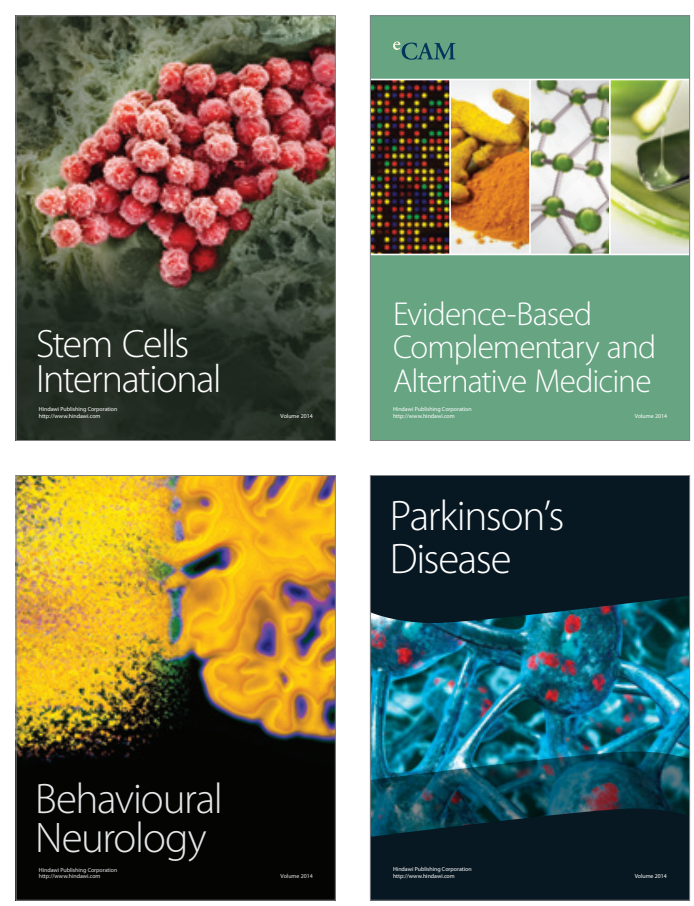

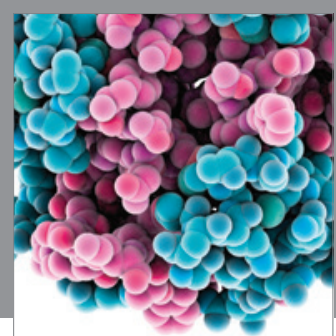

Journal of
Diabetes Research

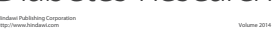

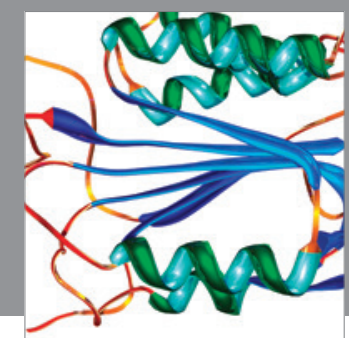

Disease Markers
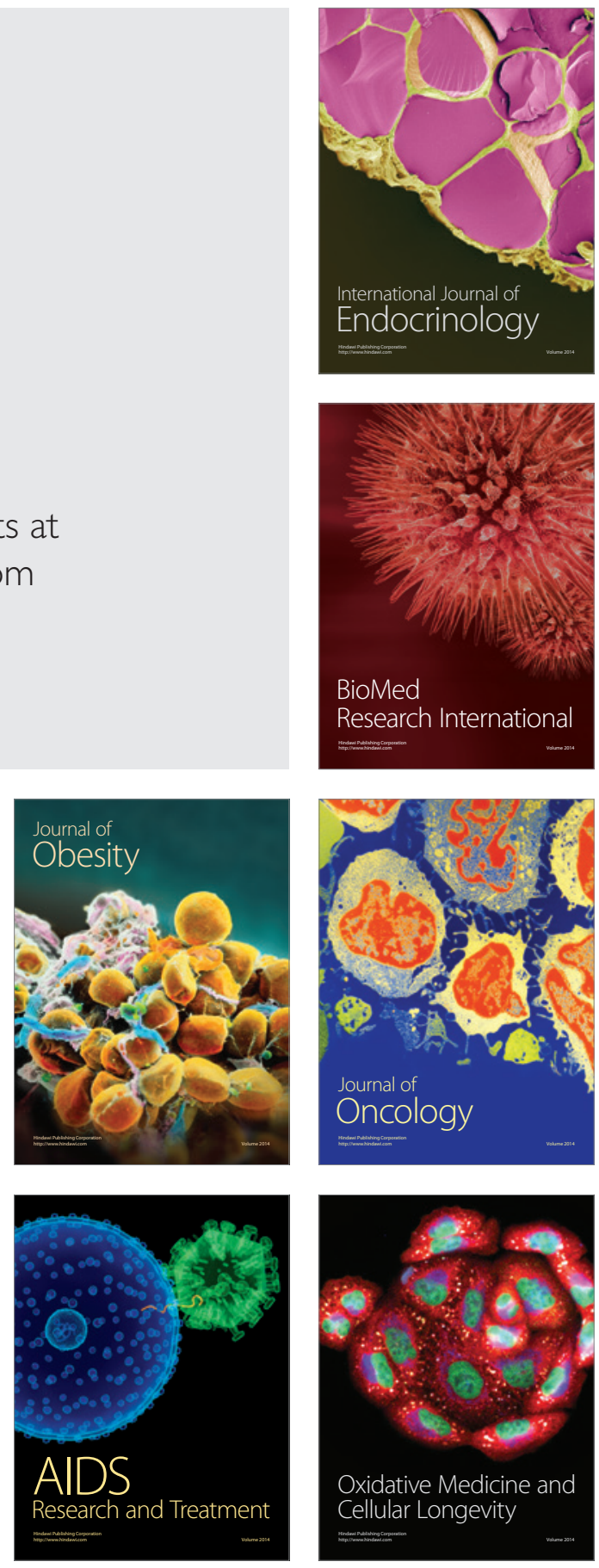